\title{
Use of medicinal plants for diabetes in Trinidad and Tobago
}

\author{
D. Mahabir ${ }^{1}$ and M. C. Gulliford ${ }^{2}$
}

\begin{abstract}
Use of herbal remedies from medicinal plants (bush medicines) was studied in 622 people with diabetes mellitus attending 17 government health centers on the island of Trinidad, Trinidad and Tobago. Bush medicines were used by $42 \%$ of patients surveyed and were used for diabetes by $24 \%$. Bush medicine use was more frequent in Afro-Trinidadians and in those of mixed ethnicity than in Indo-Trinidadians, and was also more prevalent in those with lower educational attainment. Most patients using bush medicines (214/264, or 81\%) reported gathering the plants themselves, and 107/264 (41\%) took them more frequently than once a week. Patients taking bush medicines mentioned 103 different plants used in remedies. Among the 12 most frequently mentioned, caraili, aloes, olive-bush, and seed-under-leaf were preferentially used for diabetes. Vervine, chandilay, soursop, fever grass, and orange peel were preferentially used for other indications. Patients who reported burning or numbness in the feet or feelings of tiredness, weakness, giddiness, or dizziness used bush medicines for diabetes more frequently than did patients who reported a range of other diabetes-related symptoms. Insulin-treated patients were less frequent users of bush medicines. It is concluded that bush medicines are taken regularly by many patients with diabetes in Trinidad. Plants most frequently used as remedies for diabetes have recognized hypoglycemic activity. Patients' culture, educational background, type of symptoms, and formal medical treatment may also influence the selection and use of bush medicines.
\end{abstract}

Herbal remedies from medicinal plants (known in the Caribbean as bush medicines) have been used traditionally in regions where access to formal health care is limited. There are several reasons why use of bush medicines should be studied: herbal remedies may have recognizable therapeu-

\footnotetext{
Nutrition and Metabolism Division, Ministry of Health, Trinidad and Tobago.

2 Commonwealth Caribbean Medical Research Council, and Division of Public Health Sciences, UMDS, Guy's and St. Thomas's Medical and Dental Schools, London, United Kingdom. Reprint requests and other correspondence should be addressed to this author at: Department of Public Health Medicine, St. Thomas's Hospital, London SE1 7EH, UK. Fax: 44-171-928-1468; e-mail: m.gulliford@umds.ac.uk.
}

tic effects (1); they may also have toxic side-effects (2); and use of bush medicines provides an indication of beliefs about illness and its treatment that may conflict with beliefs of workers in the formal health care system (3).

Over the last three decades chronic disorders such as diabetes and hypertension have emerged as the major causes of adult morbidity and mortality in the Caribbean islands (4). Successful control of health problems stemming from diabetes and hypertension requires active participation of patients in their own care, but as Morgan (5) has pointed out, health care providers' limited understanding of Caribbean patients' concepts of illness and ideas about treatment are obsta- cles to establishing effective patterns of self-care.

Several studies from the Caribbean region have described the plants used for medicinal purposes and have outlined the social history of bush medicine use (6-8), but there have been few epidemiologic studies of the subject. This report describes a study undertaken to investigate bush medicine use among people with diabetes in Trinidad and Tobago with a view to answering the following questions: (1) How prevalent is bush medicine use? (2) What are the sources and types of remedies used? (3) What factors are associated with the use of bush medicines by people with diabetes in Trinidad? 


\section{METHODS}

\section{Subjects}

Trinidad and Tobago provides primary medical services through a network of just over 100 health centers. Two health centers from each of eight administrative counties on the island of Trinidad were randomly selected. One health center was replaced by the outpatient clinic of a small district hospital nearby, because the latter was known to draw its patients from a wide area in the more remote eastern part of the island. One health center had a small number of attenders with diabetes, so another health center was added to the sample from that county. At each health center, patients attending the clinic for adults were selected for the survey. In most instances, these subjects were attending a designated "chronic disease clinic," but a few health centers had "health office" clinics for adult attenders with any type of medical complaint. Within each health center, subjects with diabetes were randomly sampled by using the numbers they were assigned when they queued for consultation. The aim was to interview at least 38 patients from each of the 17 health centers in order to achieve a total sample size of at least 600 .

\section{Data collection}

Subjects were interviewed by nutritionists who were staff members of the Ministry of Health's Nutrition Division and who usually worked in the health center environment. The questionnaire was written in standard English. Interviewers were instructed that it was acceptable to rephrase the questions in Trinidadian vernacular but not to prompt replies. The following questions were included concerning the use of bush medicines:

- "Many people in Trinidad use bush medicines; do you use bush medicines?"

- "Do you use bush medicines for your diabetes?"
- "Where do you get bush medicines?"

- "How often do you use bush medicines?"

- "What plants do you use for bush medicines?"

The last question was open-ended and allowed for up to six responses. When possible, specific plants were identified from standard reference works, particularly the studies by Seaforth et al. (6) and Ayensu (7).

Additional data were obtained by interview concerning patients' age, gender, self-reported ethnic group, and educational attainment. For analysis these variables were reduced to the following categories: age group ( $\leq 44 ; 45-54 ; 55-64 ; 65-74 ; \geq 75$ years); gender (male, female); self-reported ethnic group (Afro-Trinidadian, IndoTrinidadian, mixed); and educational attainment (no schooling; primary; secondary or higher; not known).

Data on patient symptoms were obtained in response to two openended questions and several closed questions concerning specific diabetesrelated symptoms. In the open-ended questions, subjects were asked to respond to the following: "Tell me the one problem from diabetes that troubles you most," and "Tell me five other problems from diabetes that trouble you." Responses were coded into broad groups. The most frequent spontaneously mentioned complaints were of foot problems, difficulty sleeping, eye problems, itching, pain, thirst and polyuria, sex problems, tiredness, weakness, giddiness, and dizziness. The last four symptoms were combined because they seemed to represent similar concepts. The closedended questions pertained to the presence or absence of itching, polyuria, difficulty with eyesight, past history of foot ulceration, and burning or numbness in the feet.

Information on drug treatments being administered for diabetes was taken from clinical notes on each patient. These treatments included insulin, sulfonylurea drugs, metformin, or a combination of sulfonylurea drugs and metformin.
Univariate analyses were performed by cross-tabulation and estimation of chi-square statistics. Multiple logistic regression analyses were performed to explore possible associations of bush medicine use for diabetes with explanatory variables (9). A single stepwise regression with backwards elimination was performed to identify any symptom or treatment variable independently associated with bush medicine use for diabetes after adjusting for age, gender, ethnicity, and educational attainment.

\section{RESULTS}

Interviews were completed for 627 subjects. Two subjects with missing age information and three identified as white or Chinese were excluded, so data were analyzed from 622 interviews. Interview data were obtained from 204 men and 418 women.

Table 1 shows frequency of bush medicine use according to ethnic group. Overall, 264 out of 622 patients, or $42 \%$, reported using bush medicines. Bush medicine use was more frequent among Afro-Trinidadians and persons of mixed ethnicity than among Indo-Trinidadians. Among bush medicine users, 152/264 (58\%) reported taking bush medicines for diabetes; use for diabetes tended to be higher among Indo-Trinidadians $(74 / 119$, or $62 \%)$ than among AfroTrinidadians (52/97, or $54 \%)$, but the difference was not statistically significant. Most patients reported collecting their own medicinal plants $(214 / 264$, or $81 \%$ ) and a few were supplied with bush medicines by friends or relatives, but little use was made of herbal shops, herbalists, or bush medicine doctors. Bush medicines were used at least every week by $107 / 264$, or $41 \%$ of patients surveyed. The frequency of bush medicine use was not clear for $56 / 264(21 \%)$ of users, possibly because they only took bush medicines when specific (and perhaps selflimiting) illnesses were experienced.

The associations of bush medicine use for diabetes with social and demographic characteristics are shown in 
TABLE 1. Use of bush medicines according to ethnic group

\begin{tabular}{|c|c|c|c|}
\hline & $\begin{array}{c}\text { Afro- } \\
\text { Trinidadian } \\
(n=188)\end{array}$ & $\begin{array}{c}\text { Indo- } \\
\text { Trinidadian } \\
(n=333)\end{array}$ & $\begin{array}{c}\text { Mixed } \\
(n=101)\end{array}$ \\
\hline & No. (\%) & No. $(\%)$ & No. (\%) \\
\hline Do you use bush medicines? (yes) ${ }^{a}$ & $97(52)$ & $119(36)$ & $48(48)$ \\
\hline $\begin{array}{l}\text { Do you use bush medicines } \\
\text { for diabetes? (yes) }\end{array}$ & $52(28)$ & $74(22)$ & $26(26)$ \\
\hline \multicolumn{4}{|l|}{ Where do you get bush medicine? ${ }^{b}$} \\
\hline $\begin{array}{l}\text { Collect own } \\
\text { Friend or relative } \\
\text { Herbal shop } \\
\text { Bush medicine doctor } \\
\text { Other/not known }\end{array}$ & $\begin{array}{l}81(84) \\
6(6) \\
2(2) \\
0(0) \\
8(8)\end{array}$ & $\begin{array}{c}89(75) \\
9(8) \\
5(4) \\
1(1) \\
15(13)\end{array}$ & $\begin{array}{l}44(92) \\
2(4) \\
0(0) \\
0(0) \\
2(4)\end{array}$ \\
\hline \multicolumn{4}{|l|}{ How often do you take bush medicine? ${ }^{b}$} \\
\hline $\begin{array}{l}\text { Every day } \\
\text { More than once a week } \\
\text { More than once a month } \\
\text { Less than once a month } \\
\text { Not known }\end{array}$ & $\begin{array}{l}16(17) \\
30(31) \\
18(19) \\
15(15) \\
18(19)\end{array}$ & $\begin{array}{c}11(9) \\
24(20) \\
27(23) \\
24(20) \\
33(28)\end{array}$ & $\begin{array}{r}10(21) \\
16(33) \\
9(19) \\
8(17) \\
5(10)\end{array}$ \\
\hline
\end{tabular}

a Percentages are of total number in that ethnic group.

b Percentages are of all bush medicine users in that ethnic group.

Table 2. There was no increase in bush medicine use with age, and gender differences were not significant. As indicated above, their use for diabetes was more frequently reported by AfroTrinidadians and persons of mixed ethnicity than by Indo-Trinidadians. Among those with secondary education $13 \%$ reported using bush medicines for diabetes, compared with $25 \%$ of those with primary school education and $26 \%$ of those with no schooling. Inclusion of health center of attendance or electoral ward of residence in regression models did not identify significant geographical variation in bush medicine use within Trinidad. Significantly higher use of bush medicines for diabetes was found in patients who responded positively to the question "Do you have burning or numbness in your feet" $(P=0.009)$ and by patients who included the symptoms tiredness, weakness, giddiness, or dizziness in their spontaneous complaints $(P=$ 0.011). Fewer patients being treated with insulin used bush medicines than patients not taking insulin.

A list of the plants used for bush medicines is given in Appendix 1 . Overall, 264 bush medicine users men- tioned 103 different plants incorporated in remedies. Plants selected as bush medicines included some commonly consumed in food or drink, for example, caraili (bitter gourd) and mauby. Others, such as vervine, chandilay, fever grass, and periwinkle, were more specifically recognizable as medicinal plants. Table 3 lists the 12 most frequently mentioned plants and shows their frequency of use for diabetes or for other indications. Caraili, aloes, olive-bush, and seed-under-leaf tended to be used preferentially for diabetes, while vervine, chandilay, soursop, fever grass, and orange peel tended to be employed for other indications. There were minor variations in the prevalence of use of different plants among the ethnic groups: vervine, olive-bush, and orange peel were less often used by Indo-Trinidadians.

\section{DISCUSSION}

This survey showed that $22 \%$ to $28 \%$ (depending on ethnic group) of patients attending government health centers for diabetes in Trinidad were regular users of bush medicines. This practice reflected an informal pattern of self-care that rarely involved practitioners of folk medicine. Selection of remedies was influenced by patients' ethnic group and educational background. The results suggested that the use of bush medicines is influenced by the type of symptoms experienced by the patient and by the type of formal treatment being received at the health centers. However, additional study would be required to explore these possibilities further. Use of remedies from medicinal plants has three main implications: such plants may have significant hypoglycemic effects; preparations from medicinal plants may also have toxic side-effects; and patients who use bush medicines may modify their use of and responses to formal treatments.

Bailey and Day (1) reviewed the hypoglycemic effects of medicinal plants and divided traditional remedies into three groups: those from which a reputedly hypoglycemic compound had been isolated; those reported to have a hypoglycemic effect but for which the nature of the active principle was not established; and those reputed to exert a hypoglycemic effect but for which the scientific evidence was equivocal. Among the plants used by the subjects in the present survey, caraili (Momordica charantia), aloe (Aloe vera), periwinkle (Catharanthus roseus), garlic (Allium sativum), and ginseng (Panax ginseng) have established hypoglycemic activity (1) Caraili (or bitter gourd) is particularly important because it is a commonly eaten vegetable and may be consumed in significant quantities. The hypoglycemic effects of extracts of Momordica charantia are well established, and the plant has been reported to cause hypoglycemia in a patient already taking sulfonylurea drugs to treat diabetes (10-12). Absent from this list of plants is ackee (Blighia sapida), whose unripe fruits cause hypoglycemia and are reported to be used to treat diabetes in Central America (1). The ackee tree is uncommon in Trinidad.

Toxic effects of herbal remedies used for diabetes have been reported. Heavy metal contamination has been 
TABLE 2. Associations of social and demographic factors with use of bush medicine for diabetes and logistic regression analyses of data

\begin{tabular}{|c|c|c|c|c|}
\hline Variable & Cases/totala $\left.{ }^{a} \%\right)$ & OR $(95 \% \mathrm{Cl})$ & Chi-square & $P$ value \\
\hline \multicolumn{5}{|l|}{ Age group (years) } \\
\hline$\leq 44$ & $14 / 69(20)$ & 1.00 & 4.94 & 0.293 \\
\hline 45 to 54 & $39 / 143(27)$ & $1.20(0.58$ to 2.49$)$ & & \\
\hline 55 to 64 & $51 / 191(27)$ & 1.05 (0.51 to 2.15$)$ & & \\
\hline 65 to 74 & $32 / 148(22)$ & $0.70(0.32$ to 1.50$)$ & & \\
\hline$\geq 75$ & $16 / 71(23)$ & 0.67 (0.28 to 1.62$)$ & & \\
\hline \multicolumn{5}{|l|}{ Gender } \\
\hline Male & 46/204 (23) & 1.00 & 0.03 & 0.872 \\
\hline Female & 106/418 (25) & 0.97 (0.63 to 1.47$)$ & & \\
\hline \multicolumn{5}{|l|}{ Ethnic group } \\
\hline Afro-Trinidadian & $52 / 188(28)$ & 1.00 & 7.14 & 0.028 \\
\hline Indo-Trinidadian & 74/333 (22) & $0.55(0.34$ to 0.87$)$ & & \\
\hline Mixed & $26 / 101(26)$ & $0.90(0.51$ to 1.60$)$ & & \\
\hline \multicolumn{5}{|l|}{ Educational attainment } \\
\hline Secondary schooling or higher & 9/68 (13) & 1.00 & 8.05 & 0.045 \\
\hline Primary school & $117 / 462(25)$ & $2.22(1.02$ to 4.80$)$ & & \\
\hline No school & 21/82 (26) & 2.68 (1.02 to 7.07$)$ & & \\
\hline Not known & $5 / 10(50)$ & 6.74 (1.53 to 29.7$)$ & & \\
\hline \multicolumn{5}{|l|}{ Burning or numbness in feet: } \\
\hline No & $51 / 272(19)$ & 1.00 & 6.91 & 0.009 \\
\hline Yes & $101 / 350(29)$ & 1.70 (1.14 to 2.55$)$ & & \\
\hline \multicolumn{5}{|l|}{$\begin{array}{l}\text { Spontaneous complaints include } \\
\text { tiredness, giddiness, weakness, } \\
\text { or dizziness: }\end{array}$} \\
\hline No & $85 / 407(21)$ & 1.00 & 6.40 & 0.011 \\
\hline Yes & $67 / 215(31)$ & 1.66 (1.12 to 2.46$)$ & & \\
\hline \multicolumn{5}{|l|}{ Insulin treatment: } \\
\hline No & $139 / 534(26)$ & 1.00 & 4.81 & 0.028 \\
\hline Yes & $13 / 88(15)$ & $0.51(0.27$ to 0.96$)$ & & \\
\hline
\end{tabular}

a Users of bush medicine for diabetes/total number of survey participants in the category.

TABLE 3. Comparison of use of 12 most frequently mentioned plants for diabetes or for other indications

\begin{tabular}{|c|c|c|c|}
\hline Plant & $\begin{array}{c}\begin{array}{c}\text { Persons using } \\
\text { plant as bush } \\
\text { medicine for } \\
\text { diabetes }(n=152)\end{array} \\
\text { No. }(\%)\end{array}$ & $\begin{array}{c}\text { Persons } \\
\text { using plant as } \\
\text { bush medicine, } \\
\text { but not for } \\
\frac{\text { diabetes }(n=112)}{\text { No. }(\%)}\end{array}$ & $\begin{array}{l}\text { Chi- } \\
\text { square }\end{array}$ \\
\hline Caraili & $43(28)$ & $12(11)$ & $12.08^{a}$ \\
\hline Vervine & $12(8)$ & $20(18)$ & $6.01^{b}$ \\
\hline Aloes & $23(15)$ & $6(5)$ & $6.30^{\mathrm{a}}$ \\
\hline Zebapique & $20(13)$ & $7(6)$ & 3.35 \\
\hline Chandilay & $7(5)$ & 15 (13) & $6.52^{b}$ \\
\hline Soursop (leaf) & 5 (3) & $16(14)$ & $10.65^{b}$ \\
\hline Olive-bush & $15(10)$ & $3(3)$ & $5.25^{\mathrm{a}}$ \\
\hline Fever grass & $3(2)$ & $14(13)$ & $11.86^{\mathrm{b}}$ \\
\hline Senna & $7(5)$ & $8(7)$ & 0.78 \\
\hline Orange peel & $1(1)$ & $11(10)$ & $12.48^{b, c}$ \\
\hline Seed-under-leaf & $10(7)$ & $1(1)$ & $5.22^{\mathrm{a}}$ \\
\hline Black sage & $5(3)$ & $5(5)$ & 0.20 \\
\hline
\end{tabular}

a Significantly more used for diabetes than for other indications.

${ }^{b}$ Significantly less used for diabetes than for other indications.

${ }^{c}$ Expected value less than five. found in herbal remedies from the Indian subcontinent (2). Such contamination seems unlikely in the Caribbean, where plants are usually harvested for immediate use. Hernandez et al. (13), in a study of medicinal plant use in Puerto Rico, reviewed the evidence that use of soursop (Annona muricata) leaf extract might carry a risk of inducing neoplasms.

This survey provides insight into patterns of informal self-care in Trinidad and Tobago. During the course of its development, the country has been subject to a range of cultural influences, including those from the indigenous Amerindian population, from Spanish and later English colonists, from immigrant populations from West Africa and later the Indian subcontinent, and from continuing interchange with Venezuela and Eastern Caribbean islands (14). Bush medicine use was common in both of the main ethnic groups, suggesting that utilization of medicinal plants is part of a shared culture. Nevertheless, there were also differences in the prevalence of bush medicine use and the selection of medicinal plants among the ethnic groups. Selection of medicinal plants showed some similarity with patterns reported from other Caribbean islands $(7,15)$. It is also interesting to compare the selection of medicinal plants in Trinidad with that reported for the population of Indian origin in Fiji (16). Several plants used in Fiji were also mentioned in Trinidad, including Ageratum conyzoides (zeb-a-fam), Momordica charantia (caraili), Mimosa pudica (teemarie), Allium sativum (garlic), Mangifera indica (mango), Cymbopogan citratus (fever grass), Tamarindus indica (tamarind), and Carica papaya (pawpaw).

Trinidad and Tobago is an uppermiddle-income country in which the importance of agricultural occupations has declined. The population has tended to concentrate in urban areas, but the main towns are small and clear-cut distinctions between urban and rural areas are difficult to make. Consistent with this pattern, there was no indication of significant geographi- 
cal variation in bush medicine use within Trinidad. Bush medicines are still widely employed despite a relatively advanced health care system that includes universal access to free prescription of pharmaceuticals. Use of bush medicines is less common among those with higher educational attainment and will no doubt continue to decline as external cultural influences become more important. The survey did not find an increase in bush medicine use with age, as might have been expected if more recent birth cohorts were less likely to continue traditional practices. However, it is possible that selection biases associated with attendance at government health centers influenced the different age groups differently.

This study represents one of the larger surveys of medicinal plant use in a middle-income country, but it was not based on a population-wide sample. By sampling from government health centers, an economically less privileged group of the population was recruited. (It should be noted that private general practice may account for half of primary care consultations in the country.) In addition, less frequent users of formal health care, among whom the use of informal folk remedies might be higher, may have been underrepresented by this sampling procedure. Medicinal plants were identified simply from the vernacular names reported by patients, and no attempt was made to collect samples for identification. Seaforth et al. (6) have pointed out that identification of species from vernacular names is sometimes unreliable because the same name may be applied to different plants in the same or different regions. Some of the analyses in this study were conducted in the spirit of exploratory data analysis without definite prior hypotheses, and the results should therefore be interpreted cautiously. Despite potential biases and limitations, these results provide an insight into the extent of use of medicinal plants for herbal remedies in a middle-income country with relatively advanced health services.
Appendix 1. List of plants that were mentioned by more than one survey participant as herbal remedies ${ }^{a}$

\begin{tabular}{|c|c|c|}
\hline Vernacular name & Latin name & $\begin{array}{c}\text { No. of } \\
\text { mentions }\end{array}$ \\
\hline Caraili & Momordica charantia & 55 \\
\hline Vervine & Stachytarpheta jamaicensis & 32 \\
\hline Aloes & Aloe vera, Aloe barbadensis & 29 \\
\hline Zebapique & Neurolaena lobata & 27 \\
\hline Chandilay, shandelier, ball bush & Leonotis nepetifolia & 22 \\
\hline Soursop, soursop leaf & Annona muricata & 21 \\
\hline Olive-bush & Bontia daphnoides & 18 \\
\hline Fever grass, lemon grass & Cymbopogan citratus & 17 \\
\hline Senna, wild senna & Cassia italica & 15 \\
\hline Orange peel & Citrus sp. & 12 \\
\hline Seed-under-leaf, button-under-leaf & Phyllanthus amarus & 11 \\
\hline Black sage & Cordia curassavica & 10 \\
\hline Christmas bush & Eupatorium odoratum & 8 \\
\hline Shining bush & Peperonia pellucida & 8 \\
\hline Carpenter grass, bush & Justicia pectoralis & 7 \\
\hline Periwinkle, old maid & Catharanthus roseus & 7 \\
\hline Shadow bennie, shadom bennie & Eryngium foetidum & 7 \\
\hline Water grass & Sambucus simpsonii & 7 \\
\hline Celery & Apium graveolens & 6 \\
\hline Boiscano, bacano, trumpet bush & Cecropia peltata & 5 \\
\hline Detipei, datapayee, obeah bush & Capraria biflora & 5 \\
\hline Ginger & Zingiber officinale & 5 \\
\hline Mauby bark, mauby & Colubrina arborescens & 5 \\
\hline Mint & [various] & 5 \\
\hline Sweet broom & Scoparia dulcis & 5 \\
\hline Whitehead broom & Parthenium hysterophorus & 5 \\
\hline Wonder-of-world & Bryophyllum pinnatum & 5 \\
\hline Karikeet, caraquite & Lantana camara & 4 \\
\hline Lime leaf, lime bud & Citrus aurantifolia & 4 \\
\hline St. John bush & Justicia secunda & 4 \\
\hline Twef/tref/threft/treft & Aristolochia trilobata & 4 \\
\hline Barbadine leaf & Passiflora quadrangularis & 3 \\
\hline Bay leaf & Pimenta racemosa & 3 \\
\hline Cerrio & Sombusus intermedia & 3 \\
\hline Garlic & Allium sativum & 3 \\
\hline Jigger bush & Tournefortia hirsutissima & 3 \\
\hline Kaisematio, kuze maho & Urena lobata & 3 \\
\hline Molasses & - & 3 \\
\hline Rabbit bush & - & 3 \\
\hline Roucou leaves & Bixa orellana & 3 \\
\hline Zeb-a-fam & Ageratum conyzoides & 3 \\
\hline Basilique & Ocimum americanum & 2 \\
\hline Bitter bush with white flower & Eupatorum villosum & 2 \\
\hline Calabash & Crescentia cujete & 2 \\
\hline Charcoal & - & 2 \\
\hline Double hibiscus, hibiscus & Hibiscus rosa-sinensis & 2 \\
\hline Honeysuckle & Bidens reptans & 2 \\
\hline Malomey & Euphorbia hirta & 2 \\
\hline Mat root & Aristolochia rugosa & 2 \\
\hline Needle bush, railway daisy & Bidens pilosa & 2 \\
\hline Paw-paw & Carica papaya & 2 \\
\hline Tamarind leaf & Tamarindus indica & 2 \\
\hline Teemarie & Mimosa pudica & 2 \\
\hline Toosie leaf/toolsie & Ocimum gratissimum & 2 \\
\hline Zabocca leaf, avocado leaf & Persea americana & 2 \\
\hline Gotokola & - & 2 \\
\hline Neeb leaf & - & 2 \\
\hline Pressure bush & - & 2 \\
\hline
\end{tabular}

a 45 others each mentioned once. 
Acknowledgments. We thank the Chief Medical Officer of Trinidad and Tobago for permission to report this study, the staff of the Nutrition
Division for their work on the survey, and Dr. David Picou for his support. We also thank Dr. M. Morgan for her comments on an earlier draft of this paper. M.C.G. was supported by the United Kingdom Overseas Development Administration.

\section{REFERENCES}

1. Bailey CJ, Day C. Traditional plant medicines as treatment for diabetes. Diabetes Care 1989;12:553-564.

2. Keen RW, Deacon AC, Delves HT, Moreton JA, Frost PG. Indian herbal remedies for diabetes as a cause of lead poisoning. Postgrad Med J 1994;70:113-114.

3. Morgan M, Watkins CJ. Managing hypertension: beliefs and responses to medication among cultural groups. Sociol Health Illn 1988;10:561-578.

4. Gulliford MC. Health and health care in the English-speaking Caribbean. J Public Health Med 1994;16:263-269.

5. Morgan M. The significance of ethnicity for health promotion: patients' use of antihypertensive drugs in inner London. Int $J$ Epidemiol 1995;24:S79-S84.

6. Seaforth CE, Adams CD, Sylvester Y. A guide to the medicinal plants of Trinidad and Tobago. London: Commonwealth Secretariat; 1983.
7. Ayensu ES. Medicinal plants of the West Indies. Algonac, Michigan: Reference Publications; 1981.

8. LaGuerre M. Afro-Caribbean folk medicine. Hadley, Massachusetts: Bergin and Garvey; 1987.

9. Dixon WJ. BMDP statistical software manual, volume II. Berkeley: University of California Press; 1991:1013-1046.

10. Leatherdale BA, Panesar RK, Singh G, Atkins TW, Bailey CJ, Bignell AHC. Improvement in glucose tolerance due to Momordica charantia (karela). Br Med J 1981;282:1823-1824.

11. Aslam M, Stockley IH. Interaction between curry ingredient (karela) and drug (chlorpropamide). Lancet 1979;1:607.

12. Ali L, Khan AKZ, Mamun MIR, Mosihuzzaman M, Nahar N, Nur-e-Alam M, Rokeya B. Studies on hypoglycaemic effects of fruit pulp, seed, and whole plant of Momordica charantia on normal and diabetic model rats. Planta Med 1993; 59:408-412.

13. Hernandez L, Muñoz RA, Miro G, Martinez M, Silva-Parra J, Chavez PI. Use of medicinal plants by ambulatory patients in Puerto Rico. Am J Hosp Pharm 1984; 41:2060-2064.

14. Brereton B. A history of modern Trinidad, 1783-1962. Oxford: Heinemann International; 1981.

15. Alleyne S, Cruikshank JK. The use of informal medication, particularly bush teas, in Jamaican patients with diabetes mellitus. Cajanus 1989;22:37-45.

16. Singh YN. Traditional medicine in Fiji: some herbal folk cures used by Fiji Indians. J Ethnopharmacol 1986;15:57-88.

Manuscript received 15 March 1996. Revised version accepted for publication on 20 August 1996.

RESUMEN El uso de remedios a base de plantas medicinales (medicinas herbolarias) se estudió en 622 personas con diabetes mellitus que asistían a 17 centros de salud gubernamentales en la isla de Trinidad, en Trinidad y Tabago. Se observó el uso de medicinas herbolarias en $42 \%$ de los pacientes encuestados y su utilización para la diabetes se observó en $24 \%$. El empleo de estas medicinas fue más frecuente en habitantes de Trinidad de herencia africana o mixta que en los de ascendencia india oriental. También fue más común en personas de baja escolaridad. La mayoría de los pacientes que usaban medicinas herbolarias $(214 / 264, \mathrm{u} 81 \%)$ dijeron que ellos mismos recogían las plantas y 107/264 (41\%) las consumían más de una vez a la semana. Los pacientes que tomaban estas medicinas mencionaron 103 tipos distintos de plantas que se usaban para hacer remedios. Entre las 12 mencionadas con mayor frecuencia, Momordica charantia ("caraili"), los áloes, Bontia daphnoides ("olive bush") y la planta Phyllantus amarus se usaban específicamente para la diabetes. La verbena, la planta Leonotis nepetifolia ("chandilay"), el guanábano, la hierba Cymbopogan citratus ("fever grass") y la cáscara de naranja se usaban más bien para otros problemas. Los pacientes que se quejaban de una sensación urente o de entumecimiento en los pies, o de cansancio, debilidad, sensación de desmayo o mareo usaban las medicinas herbolarias para la diabetes con más frecuencia que los pacientes que notificaron tener otras manifestaciones de esa enfermedad. Los pacientes tratados con insulina usaban medicamentos herbolarios con menos frecuencia. Se concluye que las medicinas herbolarias son usadas con regularidad por muchos pacientes diabéticos en Trinidad. Las plantas utilizadas con mayor frecuencia para tratar la diabetes tienen actividad hipoglicemiante reconocida. El fondo cultural del paciente, así como su grado de escolaridad, sintomatología y tratamiento médico formal, también pueden ejercer influencia en la selección y uso de los medicamentos herbolarios. 